\title{
NEWS IN BRIEF
}

\section{Scheduling problems beset delayed Mars mission}

\author{
延期された火星探査計画を悩ませる打ち上げ日程の問題
}

Nature Vol.457(248)/15 January 2009

実施が延期された米航空宇宙局 (NASA) の「マーズ・サイエンス・ラ ボラトリ (MSL)」ミッション (右写真) が、 ゆとりのない打ち上げスケジュールの中 から打ち上げ日を決めようと動き回るな かで、さらなる問題に直面している。

原子力電池駆動の探査車 MSL は、 火星上に生物が生息していたことを示 す証拠を探索することになっており、当 初の計画から 2 年遅れの 2011 年末ま でに打ち上げが予定されている。

MSL ミッションにとっての最初の打ち 上げ可能時期は 2011 年 10 月だが、
その場合には、木星の磁場と重力場を 調ベるミッションであるジュノーの打ち 上げが同年 8 月に予定されているため に厳しい制約を受けることになる。第 2 の可能時期は 12 月なのだが、そう なると火星への着陸地点は北半球が有 利になり、火星上でMSL が探査すべき 地域をめぐる論争が再燃するおそれが ある。このジレンマを解決するために、 既に大幅な予算オーバーとなっている MSL ミッションに対して 5000 万米ドル （約 45 億円）の追加支出が行われる 可能性があり、ミッション終了までの総

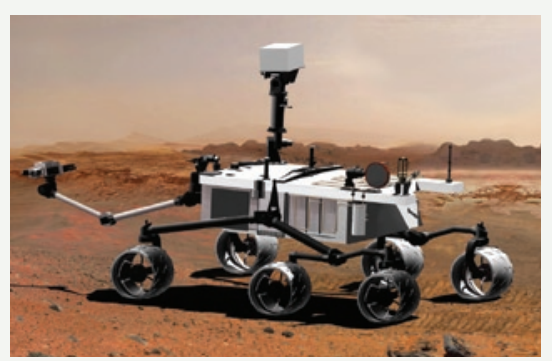

予算が最大 23 億米ドル（約 2100 億 円）まで膨れ上がることが予想される。 この記事のロングバージョンは、 http://tinyurl.com/9j3ptjを参照。 